\title{
Egészséges táplálkozási szokások kialakítása kardiológiai betegek körében: elsö tapasztalataink egy speciális dietetikai program kapcsán
}

\author{
Krizsán Annamária, Sándor Barbara, Pálfi Anita, Szabados Eszter
}

Pécsi Tudományegyetem Klinikai Központ, I. sz. Belgyógyászati Klinika, Kardiológiai Prevenciós és Rehabilitációs Tanszék, Pécs

Levelezési cím:

Dr. Szabados Eszter, 7623 Pécs, Rákóczi út 2. E-mail: szabados.eszter@pte.hu

\begin{abstract}
A kardiovaszkuláris betegségek szekunder prevenciójában kulcsfontosságú szerepet játszik a betegek sikeres életmód váltása, ezen belül a megfelelő táplálkozási szokások elsajátítása. Az elmúlt években egyre elterjedtebbé váló ambuláns kardiológiai rehabilitáció fontos része a dietetikus által vezetett étrendi tanácsadás, amely megvalósulhat egyéni és csoportos foglalkozások formájában is. Jelen közleményünkben Kardiológiai Prevenciós és Rehabilitációs Tanszékünk Dietetikai Ambulanciáján étrendi tanácsadásba bevont és egy éven keresztül rendszeresen kontrollált szív- és érrendszeri betegeinknél elért első eredményeinket szeretnénk összefoglalni.
\end{abstract}

Kulcsszavak: egészséges étrend, életmód-változtatás, ambuláns kardiológiai rehabilitáció

Establishing Healthy Nutrition Behaviors in Cardic Patients: Our First Experience with a Special Dietary Program Successful lifestyle modification including changes in dietary habits has been found to play a key role in cardiovascular prevention. Nutrition counseling held individually or in group sessions is an important element of outpatient cardiac rehabilitation.

In our present publication we summarize our first results with cardiovascular patients involved in a nutrition counseling program and controlled regularly for 1 year at the Dietary Ambulance of the Division of Preventive Cardiology and Rehabilitation.

Keywords: healthy diet, lifestyle change, outpatient cardiac rehabilitation

\section{Bevezetés}

A szív-ér rendszeri betegségek előfordulásának növekedésében a helytelen táplálkozási szokások jelentős szerepet játszanak. A kiegyensúlyozatlan, helytelen táplálkozás magában foglalja az energiadús-, de alacsony tápértékű élelmiszerek túlzott fogyasztását, a telített zsírsavak és finomított szénhidrátok túlzott bevitelét, a főleg feldolgozott élelmiszerekből származó túlzott sóbevitelt, valamint a hosszú szénláncú telítetlen zsírsavak elégtelen bevitelét, és az alacsony zöldség-gyümölcs-fogyasztást. A tartós életmód-változta- tás elérése azonban nem csekély feladat. Sikerességét több tényező határozza meg, mint például az egyén pszichoszociális helyzete, egészséggel kapcsolatos előzetes ismeretei és a betegellátó rendszer lehetőségei. Függ azonban attól is, hogy a beteg megértette-e a betegségével kapcsolatos információkat, és megfelelően motivált-e az életmódváltásban. Ennek feltétele a megfelelő, egyénre szabott betegoktatás, a rendszeres egészségügyi kontrollvizitek megszervezése, amely hosszútávon segítségnyújtás az öngondoskodó életvezetési technikák elsajátításához (1). A Pécsi Tudomány- 


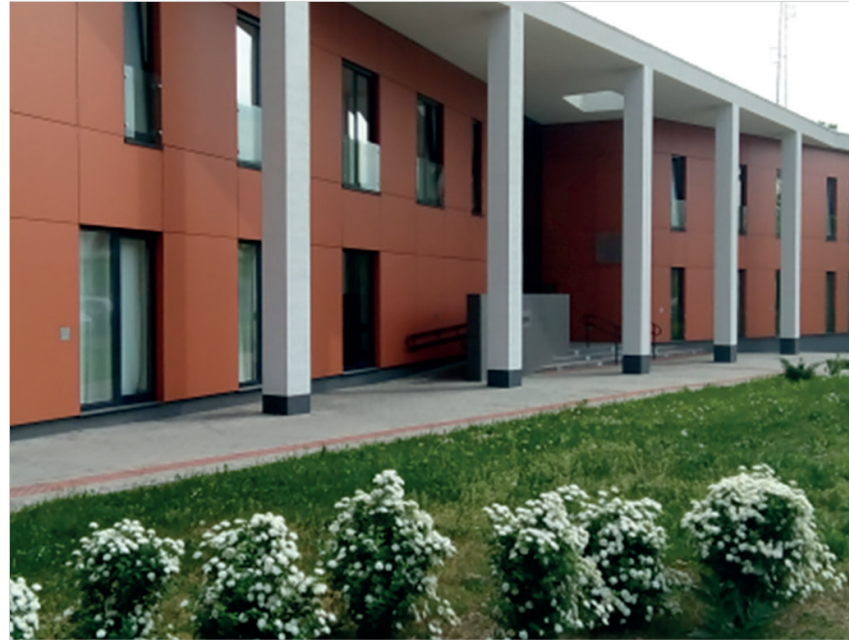

1. ÁBRA. A PTE Rehabilitációs Központ épülete

egyetem I. számú Belgyógyászati Klinika Kardiológiai Prevenciós és Rehabilitációs Tanszék Dietetikai Ambulanciája és Tankonyhája a 2015 decemberében átadott Rehabilitációs Központban került kialakításra (1. ábra). Az ambuláns dietetikai programba olyan obes betegek kerültek bevonásra, akik valamilyen kardiovaszkuláris eseményen már átestek, és korábbi testsúlycsökkentő diétájuk sikertelen volt. Jelen beszámolónkban a dietetikai ambulancián zajló munkából szeretnénk néhány eredményt bemutatni, és az ott zajló egészséges étkezéssel kapcsolatos tanácsadásból néhány szempontot kiemelni, mint az egyénre szabott energiabevitel, a zsírbevitel csökkentése, a táplálék zsírsav-összetételének megváltoztatása. Célunk az étrenddel befolyásolható rizikótényezők módosítása, a táplálkozási szokások és szemlélet tartós formálása volt.

\section{Módszerek}

Egyéni dietetikai tanácsadást követően az egészséges étkezési szokások megerősítésére a dietetikai tankony- hán csoportos tanácsadásokra került sor 2 havonta. Ennek keretén belül bemutatásra kerültek egészséges nyersanyagok, és korszerü konyhatechnológiai eljárások, majd a betegek közösen készítették el az ételt a dietetikus útmutatásai alapján. Közben folyamatos információt kaptak az alapanyagok élettani, szív- és érrendszeri rizikócsökkentő hatásairól, és a kiválasztott konyhatechnológia elönyeiről. A feldolgozott nyersanyagok mérése, energia- és tápanyagtartalmának kiszámítása fontos része volt a foglalkozásnak. A dietetikai ambulancián ellátott betegek közül 26 beteg (14 férfi és 12 nő) testtömeg-, BMI- és haskörfogat-változását követtük egy éven át. Átlagéletkoruk 51,16 év volt. Az ambulancián betegeink átlagban 2 havonta jelentek meg. Minden alkalommal egyéni elérendő célok kerültek kialakításra, megbeszélésre kerültek az elért eredmények és a további teendők. Az adatok elemzéséhez az SPSS 11.0.1 verzióját használtuk. Az adatokat normalitás vizsgálatot követően repeated measures ANOVA Greenhouse-Geisser korrekció használatával elemeztük. Az adatokat átlag $\pm S D$ formában ábrázoltuk. Statisztikailag szignifikánsnak tekintettük amennyiben a p<0,05.

\section{Eredmények}

A Dietetikai Ambulancián egy éven át követett betegek kiindulási és az egy év alatt elért értékei (testtömeg, BMI, haskörfogat) között szignifikáns különbség mutatkozott. Férfiak esetében a kiinduló testtömegértékek átlaga $(119,74 \pm 20,3 \mathrm{~kg})$, és az elért testtömegátlag $(108,1 \pm$ $14,98 \mathrm{~kg})$ között szignifikáns csökkenés igazolódott $(p<0,002)(\Delta \%$ átlag $8,44 \mathrm{~kg})$. A kiindulási BMI-adatok $\left(40,16 \pm 6,99 \mathrm{~kg} / \mathrm{m}^{2}\right)$ valamint az elért BMl-értékek $\left(36,44 \pm 5,31 \mathrm{~kg} / \mathrm{m}^{2}\right)$ között statisztikailag szignifikáns mértékü csökkenést láttunk $(p<0,012) \quad(\Delta \%$ átlag $\left.7,97 \mathrm{~kg} / \mathrm{m}^{2}\right)$. Az induló haskörfogatértékek átlaga $(127,96 \pm 17,48 \mathrm{~cm})$ és az elért haskörfogatértékek átlaga $(117,81 \pm 13,99 \mathrm{~cm})$ között szignifikáns csökkenés mutatkozott $(p<0,002)(\Delta \%$ átlag $7,53 \mathrm{~cm})(2$. ábra $)$.
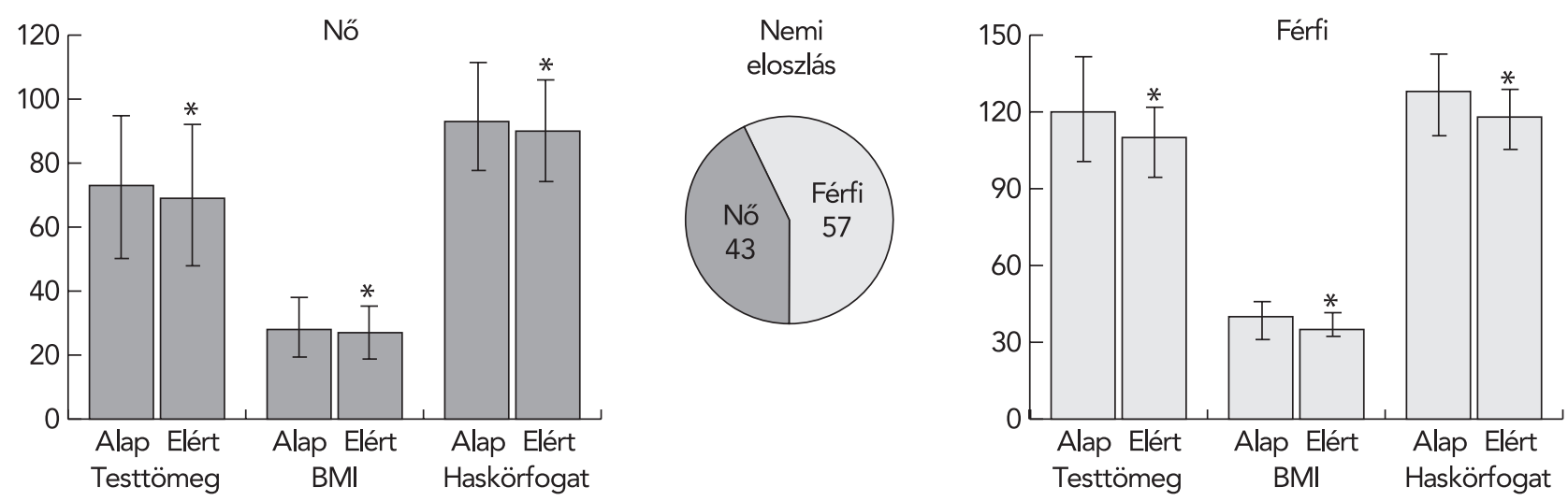

2. ÁBRA. A PTE Kardiológiai Prevenciós és Rehabilitációs Tanszék Dietetikai Ambulanciáján 1 év alatt elért testtömeg-, BMI-, haskörfogat-változások 26 beteg követése kapcsán 
Nőknél a kiinduló testtömegátlag $(73,65 \pm 21,32 \mathrm{~kg})$ és az elért testtömeg átlaga $(68,35 \pm 19,7 \mathrm{~kg})$ között szignifikáns mértékü csökkenést láttunk $(p<0,025)(\Delta \%$ átlag $5,97 \mathrm{~kg})$. A kiindulási BMI $\left(27,42 \pm 7,24 \mathrm{~kg} / \mathrm{m}^{2}\right)$ valamint az elért BMI $\left(25,2 \pm 6,64 \mathrm{~kg} / \mathrm{m}^{2}\right)$ között szignifikáns csökkenést detektáltunk $(p<0,017)(\Delta \%$ átlag $6,73 \mathrm{~kg} /$ $\left.\mathrm{m}^{2}\right)$. A kiindulási haskörfogat átlaga $(94,35 \pm 17,6 \mathrm{~cm})$ és az elért haskörfogat átlaga $(89,3 \pm 16,5 \mathrm{~cm})$ az elöbbiekhez hasonlóan szintén szignifikáns mértékben csökkent $(p<0,006)(\Delta \%$ átlag $5,18 \mathrm{~cm})$ (2. ábra).

\section{Megbeszélés}

Az egyik legnehezebb feladat a kardiológiai rehabilitáció során tartós változást elérni az életmódi szokásokban. Ezek közül is talán a legnagyobb kihívás a betegek étkezési szokásaink a megváltoztatása (1). Dietetikai ambulanciánkon erre teszünk kísérletet, amelynek során csoportos és egyéni tanácsadás, valamint a tankonyhán közös fözés kapcsán egészséges ételek elkészítése történik. A dietetikai foglalkozás során az egészséges étkezés minden aspektusa szóba kerül. Ezek közül néhányat részletesebben is bemutatunk.

\section{Egyénre szabott energiabevitel}

A testtömegtől, tápláltsági állapottól függően meghatározzuk az étrend energiatartalmát. Amennyiben nincs túlsúly, vagyis a testtömegindex (BMI) $20-24,9 \mathrm{~kg} / \mathrm{m}^{2}$ közötti (megfelelö), akkor nincs szükség fogyókúrára. A napi energia mennyiségét korhoz, nemhez, fizikai aktivitáshoz kell igazítani. Ha a BMI $25 \mathrm{~kg} / \mathrm{m}^{2}$-nél nagyobb, csökkentett energiatartalmú étrendet kell alkalmazni.
Ebben az esetben nőknek: 1200-1400 kcal/nap; férfiaknak: 1400-1600 kcal/nap energiatartalmú étrend javasolt. Túl szigorú, alapanyagcserénél alacsonyabb fogyókúrás étrend nem megengedett. A cél hosszú távú, lassú fogyókúrával a normális, vagy az azt megközelítő testsúly elérése és annak megtartása. Megfelelő mozgással kiegészítve könnyebb az eredmény elérése. A betegekkel kiszámoljuk a fogyáshoz szükséges egyéni napi kalóriaigényüket és mintaétrendet állítunk össze (1. táblázat).

\section{A zsírbevitel csökkentése}

Az összes energiabevitel legfeljebb 30\%-át tegyék ki a zsiradékok (jelenleg ez hazánkban 36-39\%). A telített zsírsavak ebböl legfeljebb 8 energia\%-ot, az egyszeresen telített zsírsavak (MUFA) 12-14 energia\%-ot, a többszörösen telítetlen zsírsavak (PUFA) pedig 6-8 energia\%-ot tegyenek ki, míg a transzzsírsavak (TFA) bevitelét a minimálisra korlátozzuk. A többszörösen telítetlen zsírsavakon belül is törekednünk kell a helyes arány eléréséhez: az omega-6:0mega-3 zsírsavak kívánatos aránya 5:1. A 2009-es magyar lakossági egészségfelmérés adatai szerint ez az érték közel 30:1, köszönhetően a napraforgóolaj dominanciájának az olajválasztás során $(2,3)$. $A z$ állati és növényi eredetű zsiradékok mennyiségét egyaránt csökkenteni kell. A zsírbevitel csökkentését zsírszegény alapanyagok felhasználásával $(2,4)$ és megfelelő konyhatechnológiai eljárások alkalmazásával lehet elérni $(2,4)$. Önmagában az összes zsiradék csökkentése, a zsírsavösszetétel megváltoztatása nélkül nem elegendő az egészséges étrend kialakításában (2).

\begin{tabular}{|c|c|c|c|c|c|c|c|}
\hline & Mennyiség & Energia (kcal) & $\begin{array}{c}\text { Energia } \\
\text { (kcal) }\end{array}$ & $\begin{array}{c}\text { Fehérje } \\
\text { (g) }\end{array}$ & Zsír (g) & $\begin{array}{l}\text { Szénhid- } \\
\text { rát (g) }\end{array}$ & Rost (g) \\
\hline \multirow[t]{4}{*}{ Reggeli } & zabpehely & $40 \mathrm{~g}$ & 156 & 6,7 & 2,8 & 22,2 & 5,08 \\
\hline & lenmag & $5 \mathrm{~g}$ & 27 & 0,9 & 2,1 & 0,1 & 1,37 \\
\hline & sovány tej & $250 \mathrm{ml}$ & 110 & 7,5 & 4,0 & 11,7 & 0,0 \\
\hline & szamóca & $100 \mathrm{~g}$ & 32 & 0,7 & 0,3 & 5,7 & 0,2 \\
\hline \multirow[t]{2}{*}{ Tízóra } & alma & $1 \mathrm{db}=150 \mathrm{~g}$ & 52 & 0,3 & 0,2 & 11,4 & 3,6 \\
\hline & Korpovit keksz & $2 \mathrm{db}$ & 44 & 1,0 & 1,25 & 6,67 & 0,8 \\
\hline \multirow[t]{3}{*}{ Ebéd } & petrezselymes bulgur & $100 \mathrm{~g}$ & 83 & 3,1 & 0,2 & 14,1 & 12,5 \\
\hline & brokkoli & $200 \mathrm{~g}$ & 68 & 5,6 & 0,8 & 8,0 & 6,0 \\
\hline & sült makréla & $100 \mathrm{~g}$ & 205 & 18,6 & 13,9 & 0,0 & 0,0 \\
\hline \multirow[t]{2}{*}{ Uzsonna } & mandula & 7 szem $\approx 20 \mathrm{~g}$ & 50 & 2,1 & 4,9 & 0,9 & 2,5 \\
\hline & narancs & $1 \mathrm{db} \approx 150 \mathrm{~g}$ & 70,5 & 1,35 & 0,15 & 14,1 & 3,6 \\
\hline \multirow[t]{4}{*}{ Vacsora } & sovány túró & $100 \mathrm{~g}$ & 95 & 14,0 & 2,8 & 3,5 & 0,0 \\
\hline & natúr joghurt & $100 \mathrm{~g}$ & 57 & 2,9 & 3,3 & 3,9 & 0,0 \\
\hline & teljes kiőrlésű kenyér & $100 \mathrm{~g}$ & 252 & 12,5 & 3,5 & 36,7 & 6,0 \\
\hline & paradicsom & $100 \mathrm{~g}$ & 16 & 1,2 & 0,2 & 2,3 & 1,0 \\
\hline Összesen & & & 1317,5 & 78,45 & 40,4 & 141,27 & 42,65 \\
\hline
\end{tabular}




\section{A telített zsírsavak fogyasztásának csökkentése}

A telített zsírsavak fogyasztásának mérséklése a koleszterinszint csökkenéséhez vezet. A legtöbb telített zsírsav állati eredetű táplálékokban található részben látható, részben rejtett zsír formájában (sertés, marha, zsíros tejtermékek, kolbászok, szalámi), ezért a diétában csökkenteni kell az állati eredetű zsiradékok arányát, a zsíros húsok, húskészítmények, zsíros tejtermékek fogyasztását (5). Ételkészítéshez minden esetben a növényi olajok jelentenek alternatívát (olíva, repce, napraforgó) (6). Megfigyelések szerint, az egyszeresen telítetlen zsírsavak, elsősorban az olajsav (omega-9, olívaolajban, repceolajban, szójaolajban, diófélékben található), telített zsírok helyett használva csökkenti a koleszterinszintet, és csökkenti a CV-rizikót (2). A többszörösen telítetlen zsírsavak közül az omega- 6 zsírsavak a növényi magvakból származnak. Napraforgó-, szója- és kukoricaolajban találhatók. 6-8 energia\% fölötti bevitel esetén azonban a szervezetben megnő a szabadgyök-képződés (növelheti a rák kockázatát), és fokozza az ateroszklerotikus folyamatok kialakulását. Az omega-3 zsírsavak a repce-, és lenmag-, dió-, és mandulaolajban találhatóak, de legfőbb forrásai a tengeri halak - ezen belül a makréla, a lazac húsa és zsiradéka. Hazai édesvízi halak is tartalmaznak omega-3 zsírsavat. Ezek közül a busa nagyobb mennyiségben, a kecsege és angolna kisebb mennyiségben. Hazánkban az omega-3 zsírsavak bevitele alacsony, előnyös CV-hatásaik miatt bevitelük növelendő (7). Foglalkozásaink során több alkalommal készítünk halat tartalmazó fogásokat, például szívbarát hallevest, natúr sült halat, halkrémet, különböző halsalátákat. A zsírsavak egy különleges csoportját alkotják a transzzsírsavak, amelyek alapvetően kétféle módon keletkezhetnek. Egyrészt mesterségesen, a növényi olajok részleges hidrogénezése során, másrészt természetes úton, a kérődző állatok anyagcseréje során. Egyes kérődzők (például tehén, kecske) teje és testzsírja is tartalmaz transzzsírokat. A vaj általános transzzsírsav tartalma például 2-4\% között van (8). Minden készétel, félkész étel megvásárlása előtt érdemes a termék transzzsírsav tartalmát ellenőrizni (részlegesen vagy teljesen hidrogénezett zsírok), mert jelentős mértékben hozzájárulnak a daganatos megbetegedések, és az ateroszklerózis kialakulásához (9). A dietetikai foglalkozáson bemutatásra kerül néhány egészséges alapanyag, és hogy bevásárlásnál mire legyenek a betegek figyelmesek (pl. mi a különbség a natúr zabpehely és az ízesített instant zabkásák között, kész salátaönteteknél milyen összetevők lehetnek kimondottan károsak, miből készítsék el helyesen otthon).

\section{Következtetés}

A diétás tankonyhai csoportfoglalkozás mind az öt érzékszervre hat, ezáltal hatékonyabb, mint a szóbeli oktatás önmagában. Eredményességét az ambulánsan mért vizsgálati eredmények bizonyítják. A Dietetikai ambulancián átlagosan 2 havonta megjelenő betegek kiindulási és az egy év alatt elért értékei (testtömeg, BMI, haskörfogat) között szignifikáns különbség mutatkozott. A szemléletformáló, egészségnevelő hatás mellett a csoportfoglalkozás pozitívan befolyásolja a betegek pszichés jóllétét és hangulatát is.

\section{Irodalom}

1. Berra K. Challenges of changing lifestyle to reduce risk for cardiovascular disease. J Cardiovasc Nurs 2010; 25: 223-227. doi: 10.1097/JCN.0b013e3181cec7e4.

2. Dietary Guidelines for Americans 2015-2020. http://health.gov/ dietaryguidelines/2015/guidelines/

3. Martos É, Kovács VA, Bakacs M, Kaposvári Cs, et al. Országos Táplálkozás és Tápláltsági Állapot Vizsgálat - OTÁP2009 I. A magyar lakosság tápláltsági állapota Országos Élelmezés- és Táplálkozástudományi Intézet, Budapest. Orvosi Hetilap 2012; 158(14): 533-540. doi 10.1556/650.2017.30700

4. http://mdosz.hu/uj-taplalkozasi-ajanlasok-okos-tanyer/

5. Dehghan M, Mente A, Rangarajan S, et al. Association of dairy intake with cardiovascular disease and mortality in 21 countries from five continents (PURE): a prospective cohort study. Lancet 2018 Nov 24; 392(10161): 2288-2297. doi: 10.1016/S0140-6736(18)31812-9.

6. Wongwarawipat T, Papageorgiou N, Bertsias D, et al. Olive Oil-related Anti-inflammatory Effects on Atherosclerosis: Potential Clinical Implications. Endocr Metab Immune Disord Drug Targets 2018; 18(1): 51-62. doi: 10.2174/1871530317666171116103618.

7. Mortazavi A, Nematipoor E, Djalali M, et al. The Effect of Omega-3 Fatty Acids on Serum Apelin Levels in Cardiovascular Disease: A Randomized, Double-Blind, Placebo-Controlled Trial. Rep Biochem Mol Biol 2018 Oct; 7(1): 59-66.

8. Estruch R, Ros E, Salas-Salvadó J, et al. PREDIMED Study Investigators. Primary prevention of cardiovascular disease with a Mediterranean diet. N Engl J Med 2013; 368(14): 1279-90. doi: 10.1056/NEJMoa1200303.

9. Wilczek MM, Olszewski R, Krupienicz A. Trans-Fatty Acids and Cardiovascular Disease: Urgent Need for Legislation. Cardiology 2017; 138(4): 254-258. doi: 10.1159/000479956. 